This item was submitted to Loughborough's Research Repository by the author.

Items in Figshare are protected by copyright, with all rights reserved, unless otherwise indicated.

\title{
Giving and social transformation
}

PLEASE CITE THE PUBLISHED VERSION

http://dx.doi.org/10.1179/1476743014Z.00000000030

\section{PUBLISHER}

(c) Taylor and Francis

\section{VERSION}

AM (Accepted Manuscript)

\section{PUBLISHER STATEMENT}

This work is made available according to the conditions of the Creative Commons Attribution-NonCommercialNoDerivatives 4.0 International (CC BY-NC-ND 4.0) licence. Full details of this licence are available at: https://creativecommons.org/licenses/by-nc-nd/4.0/

\section{LICENCE}

CC BY-NC-ND 4.0

\section{REPOSITORY RECORD}

Elder-Vass, Dave. 2019. "Giving and Social Transformation”. figshare. https://hdl.handle.net/2134/17426. 


\title{
Giving and social transformation \\ Dave Elder-Vass
}

Note: This is a pre-publication version of a paper published in the Journal of Critical Realism. It may differ slightly from the published version. Please cite as: Elder-Vass, D. (2014) 'Giving and Social Transformation', Journal of Critical Realism 13:3, 261-285, and refer to the published version for the final wording and pagination.

\begin{abstract}
Giving plays an important role in the contemporary economy, but this has been obscured by the perspectives of both mainstream economics and Marxist political economy. This paper draws on the work of J.K. Gibson-Graham to argue that this stunts our imagination about alternative futures, and on the work of Erik Olin Wright to suggest that gift-oriented economic practices could play a significant part in such futures. The most promising alternative economic futures involve not the replacement of a monolithic capitalism with some other monolithic alternative, but rather a changing mix of already-diverse economic practices. One part of the Marxist tradition that stands in the way of such thinking is its employment of the concept of modes of production, and the paper proposes complexes of appropriative practices as an alternative or supplementary concept.
\end{abstract}

Keywords: appropriative practices, diverse economies, gift economy, mode of production, real utopias.

\section{Introduction}

How can we organise for a better future ${ }^{1}$ Perhaps this question is best approached at a tangent, and this paper traces the beginnings of one such tangent. It is a tangent that starts from the notion of giving; giving both as a set of existing social practices, and giving as an element in a set of economic alternatives. Traditionally different sections of the left have advocated two routes to improving the organisation of our economy: reformist tinkering with capitalism on the one hand, or seizing the state to impose revolutionary change on the other. Neither of these, in my view, is a viable path to a radically better economy. Instead the tangent followed here passes through alternative ways of thinking about the economy that I have encountered in my work on the economic sociology of giving. The gift economy, in its various forms, does not offer an easy or a complete solution to the problem of finding better alternatives, but this paper will argue that giving

\footnotetext{
${ }^{1}$ Previous versions of this paper were presented at the IACR annual conference in Nottingham in July 2013 and at Helsinki University in February 2014. I would like to thank the attendees for their stimulating comments and questions, this journal's reviewers for their useful challenges, and indeed the many people with whom I have discussed giving for their helpful input.
} 
does provide some important parts of the answer. Furthermore, recognising its potential helps to break down some important obstacles to thinking more openly about alternative futures in general.

The paper begins by highlighting some of the ways in which the contemporary gift economy has been neglected by the social sciences. This links to an important argument from J.K. Gibson-Graham, who has/have suggested that both mainstream economics and the Marxist tradition have contributed to a highly distorted view of the economy - a view that ignores the major role that giving and other noncapitalist practices play in our economy already and as a result stunts our imagination about alternatives. I connect that in turn to the interesting and important work that Erik Olin Wright has been doing on envisioning real utopias. Wright's work helps to open up that process of imagining alternatives, partly because it implies a movement away from the monolithic conception of modes of production that has dominated left thinking about the economy for far too long. But once we recognise both the diversity of our actual economy and the diversity that would still remain in more desirable alternatives, we need to go beyond Wright and think more flexibly about economic forms. To this end this paper introduces an alternative approach organised around the concept of appropriative practices.

\section{The neglected gift economy}

Let us begin with a definition of giving. I shall use this term in what I take to be its everyday sense, that is a voluntary transfer of goods or services from one party (the donor) to another (the recipient, or recipients) that is not accompanied by an immediate transfer in return. ${ }^{2}$ On this basis we can also define the gift economy: the gift economy consists of transfers of goods and services that take the form of giving and productive activity that is undertaken with the intention of giving the product. ${ }^{3}$

The first part of my argument is that the contemporary gift economy is both extremely large and extremely significant socially, but that it has been badly neglected by the social sciences. Social scientists are often sceptical of claims that the gift economy is significant. But that scepticism, I suggest, derives from certain flawed assumptions about the nature of the economy made in both neoclassical economics and political economy. For these traditions, the economy is precisely coextensive with the commodity economy: it consists of transfers of goods and services that take the form of exchange and productive activity that is undertaken with the intention of exchanging the product. There may be grudging extensions for the state sector, which is brought back into the exchange economy by measuring it in terms of the purchase of inputs as commodities rather than in terms of the value of its outputs, but giving, and production for giving, is generally excluded without even an acknowledgement that the exclusion has taken place. The exceptions are gifts of money, and products which are produced and purchased as commodities in order to be given as gifts, which are generally of interest to economists only in their role as commodities, and cease to be of interest as soon as they have been purchased by the eventual giver of the gift.

\footnotetext{
${ }^{2}$ Any definition raises further issues. Two seem unavoidable here. First: this definition does not entail that a sale on credit counts as a gift, since in such cases the purchaser makes an immediate transfer in return, in the form of a legally binding obligation to pay later: a debt to the seller. Second, this definition does entail that various forms of sharing count as giving, such as the sharing of resources by parents with their children.

${ }^{3}$ This intention need not be the only or primary motivation of the producer for such production to count as part of the gift economy.
} 
More surprisingly, even sociologists have tended to be dismissive of the gift economy. Under the influence of the Maussian tradition of anthropology, sociologists have tended to treat giving as a marginal hangover from a pre-modern precursor to the market economy. ${ }^{4}$ As David Graeber has put it, referring to the free gift economy as communism, "The sociology of everyday communism is a potentially enormous field, but one which, owing to our peculiar ideological blinkers, we have been unable to write about because we have been largely unable to see it" ${ }^{5}$ Ironically, this has often led sociologists to focus on much the same giving practices as those that marginally interest the economists, the giving of ritual gifts at birthdays, religious festivals and the like, and to ignore other important giving practices. ${ }^{6}$

These are serious errors. We can never conceive of alternatives to the market economy if we fail to challenge the view that the economy is identical with the commodity economy. Economic alternatives are only thinkable if we take a view like that which has been developed, for example, in feminist economics and in Andrew Sayer's work on the moral economy: that the economy should be defined not in terms of commodity exchange but in terms of the provisioning of goods and services. ${ }^{7}$ When we do think of the economy in these terms, it becomes clear that giving is an economic activity in much the same sense that exchange is an economic activity, and producing to give is an economic activity in much the same sense as producing for sale. And when we look the vast range of provisioning activity that occurs in contemporary society, we soon find that an enormous proportion of it occurs outside the commodity economy.

That provisioning activity includes, for example, charitable giving, volunteering, blood and organ donation, ritual gifts on birthdays and other occasions, assistance to friends, neighbours, co-workers and indeed unknown passers-by, bequests, the creation of digital resources that are then freely shared with others on the Internet (including, for example, web pages, advice offered on Internet forums, Wikipedia pages, videos posted on YouTube, and open source software), and perhaps most substantially of all, sharing of resources and caring labour within the household.

Measuring the scale of such activity is problematic, since by definition it is not traded and thus not valued in monetary terms. Nevertheless, some hints are available in the literature as to the scale of some of these activities. For a first example, consider charitable giving. This is a worldwide phenomenon. Based on global poll data, the Charities Aid Foundation has estimated that in 2011 $45 \%$ of the world population gave help to strangers, $28 \%$ gave money to charity, and $18 \%$ volunteered their time to an organisation. ${ }^{8}$ For a second, consider what we may call digital gifts. Just one element of this is the creation of free to view web pages. Chris Anderson's "back-of-theenvelope" calculation of the unpaid effort expended on building these suggests that if it was paid at a modest rate it might cost $\$ 260$ billion a year. ${ }^{9}$

These are just tasters, though, for the main course; the most significant set of neglected economic practices, in terms of scale, is caring work in the household. While it is sometimes forced, more

\footnotetext{
${ }^{4}$ Godbout and Caillé 1998, vii. Also noted, for example, by Cheal 1988, 2; Negru 2010, 198, 200.

${ }^{5}$ Graeber 2011, 100.

${ }^{6}$ For example Berking 1999; Cheal 1988.

${ }^{7}$ Nelson 1993; Sayer 2004, 2.

${ }^{8}$ Charities Aid Foundation 2012, 6.

${ }^{9}$ Anderson 2009, 168.
} 
typically such labour can reasonably be regarded as a form of giving to those who benefit from it. ${ }^{10}$ To the extent that this is so, we may take estimates of the scale of household labour as indicators of the scale of this set of giving practices. Extensive statistical work has been done on this question, for example by Duncan Ironmonger, who concludes that in the case of Australia in 1992, and on reasonably conservative estimates of the value of household labour, "half of economic production comes from the household and half from the market" Ironmonger 1996, 53. ${ }^{11}$ If these figures are at all representative of the world economy as a whole, and if we add the many other forms of giving practices, it is reasonable to conclude that the gift economy as a whole, rather than being a marginal survival of premodern life, is at least similar in size to the market economy in contemporary society.

\section{A mixed economy}

One important implication of this argument is that the economy we live in today is far less capitalist than is usually assumed. Both neoclassical and Marxist thinkers routinely frame the contemporary economy as an essentially capitalist one (perhaps with a few minor non-capitalist survivals) swimming as it were in a non-economic sea of social practices that can largely be ignored in thinking about the economy itself. ${ }^{12}$ But if we define the economy in terms of provisioning, this is very far from being the case: giving and related practices make up perhaps half of the contemporary economy, and there are also other substantial portions of the economy that are by no means capitalist either, including the state sector but also subsistence agriculture, the self-employed and continuing pockets of slave labour.

This argument has been developed persuasively by the feminist geographers writing as J.K. GibsonGraham. ${ }^{13}$ Gibson-Graham question "familiar understandings of capitalism as a naturally dominant form of economy, or as an entire system of economy, coextensive with the social space". ${ }^{14}$ They argue that there is a dominant discourse of the economy, in which "capitalism is the hegemonic, or even the only, present form of economy". ${ }^{15}$ Given their poststructuralist leanings, Gibson-Graham are somewhat reluctant to contrast this hegemonic discourse with actual economic diversity as a

\footnotetext{
${ }^{10}$ In a context where women are expected to perform domestic labour and this expectation is backed by powerful gender norms, it may sometimes be problematic whether this is a voluntary act and thus a gift. Clearly some women enter such relationships voluntarily, and some are happy to perform this role, under the influence of these gender norms cf. Gibson-Graham 2006a, 224-5. Others may be under stronger compulsion, e.g. from domestic violence, and in such cases their work in the house must be regarded as forced labour rather than a gift. But much domestic labour is not done by women for the benefit of a dominant male partner anyway: much of it is expended on the care of children and the aged, or in single-sex relationships, or by men themselves, or in more egalitarian relationships Fraad, et al. 1994, 37-8; Gimenez 1997; Matthaei 1994, 48; Molyneux 1979.

${ }^{11}$ Williams comes to broadly similar conclusions about a range of twenty developed economies: between the 1960 s and the 1990s $44.7 \%$ of all working time in these economies was unpaid 2003.

${ }^{12}$ Although Marxists, unlike many mainstream economists, recognise the dependence of the economy on other 'non-economic' social practices.

${ }^{13}$ Gibson-Graham 2006a and b.

${ }^{14}$ Gibson-Graham 2006a, ix.

${ }^{15}$ Gibson-Graham 2006a, 2.
} 
reality that shows the discourse to be false, ${ }^{16}$ but their argument constantly tends in this direction. They describe a vast range of contemporary economic activity that does not fit the traditional model of the capitalist firm, ${ }^{17}$ arguing that "if we theorized [the economy] as fragmented... we could begin to see a huge state sector... a very large sector of self-employed and family-based producers (most noncapitalist), [and] a huge household sector". ${ }^{18}$ By no means all of these other economic practices fall within the gift economy as I have described it, and Gibson-Graham themselves see domestic labour as predominantly a feudal practice rather than as part of the gift economy. ${ }^{19}$ But they do include a broad range of giving practices within the diverse economy, and highlight a selection of these in reporting their empirical work in both the U.S. and the Philippines. ${ }^{20}$

This diverse economy is concealed by the dominant capitalocentric discourse. Mainstream academic economics, with its orientation to commodity exchange, has made an important contribution to the construction of this discourse, but Gibson-Graham argue that the same effect is produced amongst more radical thinkers by the biases of Marxist political economy. Marxists are perhaps as likely as neoclassical economists to see the contemporary economy as one that is thoroughly saturated by capitalist commodity production, and to dismiss other forms of economy as survivals from a previous age, with no more than marginal continuing significance. ${ }^{21}$ While these understandings of capitalism were developed to stimulate political action, Gibson-Graham argue that they have now become an obstacle "contributing to a crisis in left politics": ${ }^{22}$

Part of what produces the disarray of the left is the vision of what the left is arrayed against. When capitalism is represented as a unified system coextensive with the nation or even the world, when it is portrayed as crowding out all other economic forms, when it is allowed to define entire societies, it becomes something that can only be defeated and replaced by a mass collective movement (or by a process of systemic dissolution that such a movement might assist). ${ }^{23}$

Given the absence of such movements and the utter implausibility of such systemic dissolutions in the current historical context, this perspective acts as "a brake upon the anticapitalist imagination": $: 24$ it obscures the possibility, above all, that anticapitalist alternatives might be developed within the supposedly purely capitalist economy that we already have. Indeed it is not only a cognitive obstacle but also an emotional one: if to imagine incremental alternatives is necessarily fruitless, then there seems to be little point in hoping for anything better than social democratic tinkering in a thoroughly capitalist economy.

Gibson-Graham themselves tend to see the alternative in linguistic terms: they seek to develop "a language of the diverse economy" ${ }^{25}$ in order to "disarm and dislocate the naturalized dominance of

\footnotetext{
${ }^{16}$ See, for example, Gibson-Graham 2006a, xii.

${ }^{17}$ For example, Gibson-Graham 2006a, xii-xv.

${ }^{18}$ Gibson-Graham 2006a, 263.

${ }^{19}$ Fraad, et al. 1994; Gibson-Graham 2006a, 61.

${ }^{20}$ Gibson-Graham 2006b, 150, 175-6.

${ }^{21}$ There are exceptions: Gibson-Graham are not the only thinkers to have challenged this aspect of Marxist thinking (see below).

${ }^{22}$ Gibson-Graham 2006a, 1.

${ }^{23}$ Gibson-Graham 2006a, 263.

${ }^{24}$ Gibson-Graham 2006a, 3.

${ }^{25}$ Gibson-Graham 2006b, 60.
} 
the capitalist economy and make a space for new economic becomings". ${ }^{26}$ Most realists, I suspect, would feel that Gibson-Graham overstate the contribution that language can make, and understate the impact of the systemic forces of capitalism on our options, but the central thread of their argument is both sound and important. There is a powerful tendency on both left and right to think of the contemporary economy as thoroughly capitalist; this does obscure the existence of a vast range of noncapitalist economic practices in the contemporary economy; and that does discourage us from thinking of the development of such practices as a central plank of anticapitalist politics. But if we reject that discourse we can begin to see the situation as less desperate: we are already surrounded by a range of viable and in some cases even thriving noncapitalist economic practices, and developing those alternatives is an important part of a viable anticapitalist strategy.

This is not to deny the central role of capitalism in important sectors of the contemporary economy. Capitalism certainly dominates mechanised industrial production, for example, and has driven the development of much of the technology that has transformed human lives over the last two or three centuries. Nor is it to claim that there is some alternative comprehensive system standing ready to saturate economic space, as Marxists have often thought that socialism or communism might do. But capitalism itself is not a comprehensive system saturating economic space. Rather, it is a discursively and politically dominant element in what l'd like to call a mixed economy of practices: not, that is, a mixed economy of the state sector and the capitalist sector, but a far more diversely mixed economy.

\section{Envisioning alternative mixes}

Once we have recognised that our existing economy is already a diverse mixed economy of practices, it becomes easier to see the value of nurturing and supporting alternative economic practices that provide, not comprehensive alternatives to capitalism, but limited and partial elements in the changing mix of practices in the diverse economy. Again, important work has already been done in this area, notably under the banner of Erik Olin Wright's Real Utopias project.

A series of books by a variety of authors have appeared in the Real Utopias series, but Wright's programme is outlined most comprehensively in his own book Envisioning Real Utopias. ${ }^{27}$ Wright abandons the traditional Marxist approach to alternatives to capitalism, which is largely to leave the future in the lap of the party and/or the anonymous forces of history. ${ }^{28}$ Instead, he argues, we need to think constructively about alternatives, and where possible start developing them now. These alternatives are his real utopias. They are utopian in the ethical sense that they are visions for "social institutions free of oppression", visions that expand our imagination about what is possible. ${ }^{29}$ But they are also real in the sense that a proposal only qualifies as a real utopia if we can make a good case that it is viable and achievable. An alternative is viable if it would, when implemented, generate "the emancipatory consequences that motivated the proposal", ${ }^{30}$ and it is achievable if there is a

\footnotetext{
${ }^{26}$ Gibson-Graham 2006a, xii.

${ }^{27}$ Wright 2010.

${ }^{28}$ An approach which has also been criticised, for example, by Andrew Sayer 1995, 14.

${ }^{29}$ Wright 2010, 6.

${ }^{30}$ Wright 2010, 21.
} 
plausible path by which we could arrive at it: real utopias must be what Wright calls "destinations that have accessible waystations". ${ }^{31}$

There is a strong resemblance here to Roy Bhaskar's concept of concrete utopianism, which he defines as "the exercise of constructing models of alternative ways of living on the basis of some assumed set of resources, counterbalancing actualism and informing hope". ${ }^{32}$ Bhaskar's introduction of sets of resources here implies that our utopian constructions should be feasible and viable in plausibly imaginable circumstances, while the reference to counterbalancing actualism suggests the need, as Wright suggests, to "expand our imagination" beyond what seems possible in the present circumstances. The purpose, Bhaskar writes, is "to pinpoint the real, but non-actualized, possibilities inherent in a situation, thus inspiring grounded hope". ${ }^{33}$ Perhaps the most significant distinction between Wright's discussion and Bhaskar's is not so much the content of their concepts as the contexts in which they employ them. Bhaskar's concrete utopias appear in a deeply philosophical account of the potential for social transformation, whereas Wright's real utopias feature in an argument that is more directly related to the construction of practical political programmes.

There are many attractive features of Wright's project. One is that he thinks carefully through the issues involved in emancipatory social science. It involves, he argues, "three basic tasks: elaborating a systematic diagnosis and critique of the world as it exists; envisioning viable alternatives; and understanding the obstacles, possibilities, and dilemmas of transformation" and he stresses that "all are necessary for a comprehensive emancipatory theory". ${ }^{34}$ Another is that he recognises the inherently ethical nature of both the task of critique and the development of alternatives, and explicitly outlines the ethical basis on which he builds: a "radical democratic egalitarian understanding of justice". ${ }^{35}$ Third, and unlike Gibson-Graham, he recognises that capitalism has systemic tendencies to generate harms that are not purely dependent on the accompanying discursive regime and documents these thoroughly. ${ }^{36}$ Fourth, he recognises the resistance of the current system to change and examines strategies for addressing the obstacles this generates. ${ }^{37}$ Fifth, he recognises that the future is open, rather than driven to some inevitable conclusion by the contradictions of capitalism, and thus that a successful emancipatory programme would not lead to a kind of perfect steady state society but rather to a continuing process of open contingent development. ${ }^{38}$

What makes Wright's project particularly compatible with the argument being developed here, however, is that many of his utopias are not totalising blueprints, not designs that purport to offer a new "unified system... crowding out all other economic forms", 39 but medium sized proposals for the

\footnotetext{
${ }^{31}$ Wright 2010, 6. Both this attention to viability and achievability, and Wright's explicit enunciation of the ethical agenda underlying his real utopias, develop arguments that have been offered by Andrew Sayer Sayer 1997.

32 Bhaskar 1993, 395; Hartwig 2007, 74-5.

33 Bhaskar 1994, 112 fn 1.

${ }^{34}$ Wright 2010, 10.

${ }^{35}$ Wright 2010, 12.

${ }^{36}$ Wright 2010, 37.

${ }^{37}$ Wright 2010, 273.

${ }^{38}$ Wright 2010, 107-9, cf. Bhaskar 1993, 297.

${ }^{39}$ Gibson-Graham 2006a, 263.
} 
redesign of social institutions that can be mixed diversely. ${ }^{40}$ Thus it is possible for many of these utopias to be developed as what he calls "interstitial processes". ${ }^{41}$ As Wright points out, capitalism itself can be seen as "having developed in the interstices of feudal society" ${ }^{42}$ Capitalism was only able to establish its discursive and political dominance, and only able to develop to the extent that makes possible its systemic consequences, as a result of the growth of capitalist practices within an earlier mixed economy of practices. New economic practices, beyond perhaps simple shifts in ownership, cannot be created on a large scale overnight and expected to run smoothly the next day; on the contrary, they need time to grow and mature. Hence any workable economic alternatives will almost certainly need to develop initially within the current context. There is therefore a strong parallel between Wright's argument and the anarchist strategy of "forming the structure of the new society within the shell of the old" ${ }^{43}$ and a major focus of his project is identifying existing practices that can form the basis of real utopias. ${ }^{44}$ Indeed this vision also converges with more anarchist understandings of utopia in rejecting the idea of a single blueprint to be imposed universally. ${ }^{45}$

Wright examines both political and economic innovations but it is the economic examples that are relevant to this paper. Some of his utopias would require large scale change driven by state power, such as an unconditional basic income, ${ }^{46}$ John Roemer's proposals for market socialism, ${ }^{47}$ and Michael Albert's "non-market participatory democratic economy". ${ }^{48}$ Others, however, are based on actually existing economic practices, such as worker co-operatives, which he examines through the case of the Mondragón group in the Basque area of Spain, ${ }^{49}$ social enterprises, where he focuses on the organisation of child and elder care in Quebec, ${ }^{50}$ and Wikipedia. ${ }^{51}$

The very idea that such practices can develop within the existing economy clearly depends on the assumption that the economy is in some sense a mixed economy, as Wright recognises. Although he describes capitalism as "a particular way of organizing the economic activities of a society" ${ }^{52}$ which seems to imply a view of capitalism as a totalising form, he nevertheless acknowledges that no society is ever purely capitalist, or indeed purely socialist. ${ }^{53}$ He recognises work like domestic labour and volunteering as economic, ${ }^{54}$ and thus as prompting a challenge to the view that we can characterise the economy as simply a capitalist economy. The presence of these other forms, and indeed of state enterprise, "can be understood as reducing the 'capitalisticness' of the economy", and yet he continues: "to the extent that these variations all retain the core elements of the institution of private property in the means of production and markets as the central mechanism of

\footnotetext{
${ }^{40}$ Wright 2010, $x$.

${ }^{41}$ Wright 2010, 323.

${ }^{42}$ Wright 2010, 323.

${ }^{43}$ Constitution of the Industrial Workers of the World, cited in Wright 2010, 325.

${ }^{44}$ Wright does, however, distance himself from the anarchist view that emancipatory struggles can ignore the state: for Wright, the state too is "an arena of struggle" that cannot be neglected 2010, 335-6.

${ }^{45}$ Kinna 2014.

${ }^{46}$ Ackerman, et al. 2006; Wright 2010, 217-222.

${ }^{47}$ Roemer 1994; Wright 2010, 247-52.

${ }^{48}$ Albert 2003; Wright 2010, 252-65.

${ }^{49}$ Wright 2010, 234-46.

${ }^{50}$ Wright 2010, 204-15.

${ }^{51}$ Wright 2010, 194-203.

${ }^{52}$ Wright 2010, 34.

${ }^{53}$ Wright 2010, 124.

${ }^{54}$ Wright 2010, 36.
} 
economic production, they remain varieties of capitalism" ${ }^{55}$ Wright even recognises that this opens up what he calls "a knotty theoretical problem": in these circumstances, "what justifies still calling the system as a whole 'capitalism'? How much non-capitalism is needed before the resulting hybrid is something entirely new rather than a hybrid form of capitalism as such?". ${ }^{66} \mathrm{He}$ is unwilling to let go of the belief that our contemporary economy is a capitalist economy, but goes so far as to admit that "The use of the simple, unmodified expression 'capitalism' to describe an empirical case is thus shorthand for something like 'a hybrid economic structure within which capitalism is the predominant way of organizing economic activity", ${ }^{57}$ and to recognise that there is no simple answer to "the question of what precisely is meant by the claim that capitalism is 'dominant' within a hybrid configuration". ${ }^{58}$

Wright, then, goes a long way towards recognising what I have called the mixed economy of practices, but there are still some crucial absences from his work. First, like most social scientists, he remains blinkered about the sheer extent of non-capitalist economic activity in the existing economy, which allows him to maintain the view that the contemporary economy is fundamentally a capitalist economy. Even the term "interstitial" that he uses to refer to alternative developments within the existing system reveals a sense that those alternatives occupy small gaps in a predominantly capitalist structure. Second, as a result, he fails to see the need to theorise all economic systems as hybrid. There is a clinging here to a certain version of the Marxist concept of modes of production as historical stages that will be questioned later in this paper. And third, his neglect of the gift economy is also linked to a neglect of the emancipatory possibilities offered by developments in the gift economy.

\section{The emancipatory potential of the gift economy}

Recently, Wright has taken a welcome step towards correcting this third neglect by including a piece by Yochai Benkler in a special issue of Politics and Society on the Real Utopias project. ${ }^{59}$ Benkler has written a series of important papers and books describing what he calls "commons-based peer production" ${ }^{60}$ or "sharing", 61 a form of production in which large numbers of individuals participate voluntarily in the production of benefits that are then made freely available - an element, in other words, of the contemporary gift economy. Benkler's work is solidly supported with a wide range of actually functioning examples, many of them drawn from the digital information economy, and he has argued that "sharing is a pervasive modality of economic production", if we define economic production as "the provisioning of goods and services that people value". ${ }^{62}$

Benkler argues that "Commons-based peer production has come to play a large role in the construction of the networked environment, networked culture, and the networked social order". ${ }^{63}$ It accounts for much of the standard-setting activity that has shaped the design of the Internet itself,

\footnotetext{
${ }^{55}$ Wright 2010, 36.

${ }^{56}$ Wright 2010, 36.

${ }^{57}$ Wright 2010, 125

${ }^{58}$ Wright 2010, 126

${ }^{59}$ Benkler 2013.

60 Benkler 2002, 375.

${ }^{61}$ Benkler 2004, 275.

62 Benkler 2004, 331.

63 Benkler 2013, 214.
} 
for the "development of some of the core software utilities that run the Web" and indeed for a great deal of other widely-used software, and for the free web encyclopaedia Wikipedia. ${ }^{64}$

Wikipedia is a particularly pure case of the gift economy in action..$^{65} \mathrm{It}$ is created entirely by unpaid volunteers, and indeed anyone can edit (almost) any Wikipedia page. It is run with minimum levels of hierarchy, with disputes being resolved largely by the achievement of consensus under the guidance of a well-developed set of normative standards, and only rarely by the intervention of administrators, who are themselves volunteers selected on the basis of their previous contributions to the project. ${ }^{66}$ Its product is freely available to anyone who chooses to make use of it. Its running costs are low given the enormous levels of usage - at the time of writing it is the seventh most visited site on the $\mathrm{Web}^{67}$ - and are met entirely by soliciting voluntary donations from users; indeed the site does not even accept advertising.

The phenomenon of open source software is a less pure case but an equally interesting one. ${ }^{68}$ This is software that is supplied (generally for free) along with its humanly-readable program code so that anyone with the appropriate skills can modify or extend it, and under license conditions that permit users to do exactly that. ${ }^{69}$ This provides the basis for cooperative development of the software, as any programmer can make improvements. Programmers who are interested in contributing to a product are free to choose what work to do on it, and then offer their improvements back to the open source community. An element of hierarchy does exist in these communities, as groups exist which consolidate the most successful modifications into new releases of the product, but despite this there is an unusually low level of hierarchy and centralised control given the complexity of the product. Nevertheless, open source communities have developed some of the most successful software in the world: an organisational feat that would previously have been considered impossible. ${ }^{70}$ Benkler reports, for example, that such software accounts for "roughly three-quarters of web servers" and "more than 70 percent of web browsers". ${ }^{71}$ It also includes Linux, an operating system that is used by most of the major website providers, and Android, a variant of Linux that is now the most widely-used smartphone operating system in the world. ${ }^{72}$

Open source software and Wikipedia's web site are given freely to their users, and developed in a decentralised collaborative fashion using freely donated labour. Individuals contribute to it partly out of the sheer "pleasure of creation", ${ }^{73}$ the pleasure of unalienated labour, in which the worker chooses her task, controls her own labour process and product, can interact with others involved in the process as a free and equal individual, and can exercise her creativity for the wider benefit of humanity. ${ }^{74}$ This is labour freed from the tyranny of the market, a kind of labour that is sometimes denigrated as a mere hobby, and yet a kind of labour that is intensely productive of the flourishing

\footnotetext{
${ }^{64}$ Benkler 2013, 214.

${ }^{65}$ This paragraph is based largely on material from O'Sullivan 2009, and Reagle 2010.

${ }^{66}$ Forte, et al. 2009.

${ }^{67}$ Alexa.com 2013.

${ }^{68}$ For more on open source software as a form of gift economy, see Elder-Vass 2014.

${ }^{69}$ Stallman 2010, 3.

70 Benkler 2013, 214.

${ }^{71}$ Benkler 2013, 220.

72 Linux Foundation 2012.

73 Benkler 2002, 424.

${ }^{74}$ By contrast with alienated labour as described in Marx 1978 [1844], 74-6.
} 
that our economies so often fail to generate. This is a model of economic production with overtones of Marx's vision of communism and Kropotkin's anarchistic view of societies based on mutual aid, ${ }^{75}$ and it seems to fit very clearly with the agenda of developing noncapitalist economic practices.

It is also a model of production that is enabled and encouraged by the particular socio-technical characteristics of the Internet. Where the product is information, the costs of duplicating and sharing that information are now trivial, and because information is a nonrival good, a good which can be used by multiple consumers without reducing its availability to others, its benefits are not reduced by widespread sharing. Benkler argues that in such contexts "the primary remaining scarce resource is human creativity. And it is under these conditions that the relative advantages of peer production emerge to much greater glory than possible before".$^{76}$ Indeed, in this context intellectual property rights that restrict such sharing are often an obstacle to the efficient social use of information. ${ }^{77}$ There are hints here of Marx's argument that changes in the forces of production may lead to the existing social relations of production becoming fetters on the further development of production, but Benkler is less ambitious than this; his argument is that technological changes are simply making possible a shift in the balance of production towards commons-based peer production. $^{78}$

Indeed it seems unlikely that Benkler's model could work for all kinds of production - most obviously large-scale mechanised industry, which depends on larger capital investments than most cooperating individuals are able to make. Commons-based peer production, then, is not being advanced as a universal replacement for capitalism, let alone a model for an entire economy.

However, there are also other reasons to be cautious about overstating the potential of the digital gift economy. As was intimated above, not all digital gifts are entirely distinct from the capitalist commodity economy. Open source software, notably, is deeply intertwined or enmeshed with capitalist commodity relations. ${ }^{79}$ Many of the programmers who contribute to open source software are not independent individuals: in the case of the Linux kernel, for example (which may not be representative), only $17.9 \%$ of the changes made between 2005 and 2012 were made by unaffiliated individuals. ${ }^{80}$ The vast majority were made by programmers working for commercial software companies, notably Red Hat, Novell, Intel and IBM (these four contributed over $30 \%$ of the changes). ${ }^{81}$ While the data collection method means that some of these programmers may have been working on the project in their own time, it is clear that most of it is paid work, done for commercial companies, who are the real donors of this work to the project.

This work is still a gift, ${ }^{82}$ and the open source software that results from it is still made freely available to its consumers, but the motives behind these contributions are primarily profit oriented. IT services companies, for example, who are actively involved in developing an open source product

\footnotetext{
${ }^{75}$ Kropotkin 2006 [1902].

${ }^{76}$ Benkler 2002, 377-8, also see 404.

${ }^{77}$ Benkler 2002, 445-6.

${ }^{78}$ Benkler 2004, 341.

${ }^{79}$ Cammaerts 2011.

${ }^{80}$ Corbet, et al. 2012, 9.

${ }^{81}$ Corbet, et al. 2012, 9.

${ }^{82}$ As Donati says, "A free gift is a unilateral transfer and without conditions, but subsequent exchange is not excluded" 2003, 246.
} 
develop deep expertise that enables them to provide support and integration services to companies that wish to use that product, and can offer, for example, to write fixes and new function for a customer which will then become part of the open source product. ${ }^{83}$ Red Hat, for example, market themselves as "The world's leading provider of open source enterprise IT products and services". ${ }^{84}$

Many other digital gifts are also given for commercial motives. Google's search results, YouTube's videos, and Facebook's status updates, for example, are given to us as gifts (and indeed by us in some cases) but also present Google, YouTube (owned by Google), and Facebook with prime advertising opportunities, ${ }^{85}$ and there are many free games available on a variety of digital platforms that create selling opportunities for the companies that build them. ${ }^{86}$ As Christian Fuchs has pointed out, on the Internet we constantly find "an entanglement of gifts within the commodity form". ${ }^{87}$

Such entanglements point us towards an important feature of the mixed economy of practices: our diversely mixed economy is not neatly divided into sites that fit unambiguously within one mode of production or another. On the contrary, the mixing of practices penetrates deep within the various sites of the economy.

\section{Problematising modes of production}

This paper has so far skirted around the question of the social ontology of economic forms, a question answered in the Marxist tradition using the concept of modes of production - a concept that has often seemed relatively uncontroversial. The argument that capitalism replaced feudalism as the dominant mode of production in Europe, for example, is a staple of sociological accounts of modernity, and the idea that social progress consists in replacing capitalism in its turn remains a central plank of radical politics. But the discussion above has repeatedly cast doubt on some of the senses in which the concept is routinely used. The remainder of this paper will examine those doubts more thoroughly and discuss what kind of response to them might be appropriate. In the process it will draw on and criticise some of the late twentieth century Marxist literature, although there is a vast range of Marxist writing it will leave untouched.

The classic source of Marx's concept is the 1859 Preface, which outlines in one long paragraph Marx's theory of history. After introducing the "relations of production" and the "productive forces", Marx tells us that "The sum total of these relations of production constitutes the economic structure of society, the real foundation, on which rises a legal and political superstructure and to which correspond definite forms of social consciousness. The mode of production of material life conditions the social, political, and intellectual life process in general". ${ }^{88}$ And a little later: "In broad outlines Asiatic, ancient, feudal, and modern bourgeois modes of production can be designated as progressive epochs in the economic formation of society" ${ }^{89}$ Even in these first two references to the concept a degree of ambiguity can be detected. In the first reference, mode seems to refer rather

\footnotetext{
${ }^{83}$ Anderson-Gott, et al. 2011, 109; Weber 2004, 195-203.

${ }^{84}$ Red Hat 2012.

85 Levy 2011, chapter 2.

${ }^{86}$ Elder-Vass 2014.

${ }^{87}$ Fuchs 2008, 171.

${ }^{88}$ Marx 1978 [1859], 4, emphasis added.

${ }^{89}$ Marx 1978 [1859], 5, emphasis added.
} 
loosely to the manner in which production occurs. ${ }^{90}$ By the second, it has become identified with some specific economic structures that define successive stages in the development of society.

On the whole it is the latter usage that has prevailed in the Marxist tradition. Étienne Balibar, for example, despite his acknowledgement that mode has something of the sense of manner, identifies modes of production with states of the economic structure, and tells us that "the history of society can be reduced to a discontinuous succession of modes of production". ${ }^{91}$ Similarly, in a formulation that makes sense only if modes of production dominate societies, Althusser proposes that different modes of production produce a different "society-effect". ${ }^{92}$

While there has often been some recognition that particular societies might include elements of multiple modes of production, Marxists have tended to marginalise this issue. As Hodgson puts it, "Although he acknowledged their real existence, when analysing the capitalist system in Capital, Marx ignored all the non-capitalist elements in that system. This was not merely an initial, simplifying assumption. They were assumed away at the outset, never to be reincorporated at a later stage of the analysis". ${ }^{93}$ More recently, the work of Althusser and Balibar examines the relation between the economic contradictions of capitalism and contradictions in the superstructure, but largely ignores the problem of the relation between different economic forms, except as a feature of periods of transition between the epochs of one mode of production and another. Balibar does hypothesise "modes of production which have never existed in an independent form" such as commodity production by individuals, but without any consideration of how they might appear in combination with other modes of production in practice. ${ }^{94}$

Thinkers in the Althusserian Marxist tradition have sometimes argued that there may be multiple modes of production within what they refer to as a social formation, ${ }^{95}$ but they see tend to see these as standing in a relation of dominance and subordination. John Harrison, for example, in postulating a "housework mode of production", "argues that within a determinate social formation there may be subordinate modes distinct from the dominant, constitutive modes" - subordinate modes that may be vestiges of past modes, initial traces of future modes, or client modes "created or co-opted by the dominant mode to fulfil certain functions". ${ }^{96}$ Molyneux criticises Harrison for offering an argument that is inconsistent with both Balibar's and more traditional conceptions of the mode of production because this household mode "could never become generalised" to the whole economy. ${ }^{97}$ There is a strong sense here that for Marxists the mode of production is to be seen as a single dominant form of social relations that either constitutes or dominates all economic practice within the social formation concerned.

G.A. Cohen, while using the term mode of production rather differently, substitutes the concept of social forms and uses it in much the same way as these other thinkers use mode of production. For Cohen capitalism, feudalism, and the like are successive social forms of economic structure, and

\footnotetext{
${ }^{90}$ Cf Althusser and Balibar 2009 [1968], 235; Cohen 1978, 79.

${ }^{91}$ Althusser and Balibar 2009 [1968], 228.

${ }^{92}$ Althusser and Balibar 2009 [1968], 71.

${ }^{93}$ Hodgson 1999, 124.

${ }^{94}$ Althusser and Balibar 2009 [1968], 242.

${ }_{95}$ Hindess and Hirst 1972, 46-7.

${ }^{96}$ Molyneux 1979.

${ }^{97}$ Molyneux 1979.
} 
although he acknowledges the theoretical possibility of diverse social relations coexisting within an economic structure, he sees Marx as assuming that "the production relation binding immediate producers will be broadly invariant across a single social formation" ${ }^{98}$ Cohen does recognise that there is always likely to be some mix of production relations in any given social formation, but immediately trivialises this possibility by arguing that "In real and stable economic structures, one kind of production relation binding immediate producers is dominant". ${ }^{99}$

Within the critical realist tradition, Andrew Sayer has argued somewhat more openly for the idea that "actual economies combine several different forms of organization". ${ }^{100}$ Bob Jessop, drawing on the regulation approach, has stressed the dependence of capital on "other systems and the lifeworld" ${ }^{101}$ though he tends to present that which lies outside capitalism as the "extraeconomic", ${ }^{102}$ thus reinforcing the dominant Marxist tendency to identify the economy itself purely with capitalism in contemporary social formations.

This treatment of modes of production as economic forms that dominate a society, while other forms are essentially marginal, is clearly problematic in the light of the earlier sections of this paper. The coexistence of economic forms is not a purely transitional phenomenon but a permanent feature of all complex economies, and even our contemporary society is one where capitalist economic activity is in the minority. Hence we need to retheorise this space that is currently occupied by an essentially monolithic concept of the mode of production - not only because this concept fails to accommodate contemporary social reality, but also because that failure is politically consequential. In obscuring the diversity of noncapitalist practice in existing society it directs the attention of those seeking economic alternatives away from the possibility of developing alternative forms within a diverse economy. This monolithic conception of the economy leads directly to a monolithic conception of political action, in which control of the state becomes the only route and the wholesale replacement of one economic monolith with another becomes the only destination.

\section{Retheorising modes of production?}

How might we go about retheorising economic forms? One way forward might be to build on Cohen's suggestion that we use mode of production in something close to the first of the two senses employed in the Preface: "A mode of production is a way of producing". ${ }^{103}$ While this moves us in the right direction, I think, I doubt whether we can successfully detach such a widely used concept from the ways in which it is customarily employed, and this paper will therefore suggest new terms. The concept of a "way of producing", of course, is spectacularly vague, and Cohen himself goes on immediately to point out that "there are many ways of differentiating ways". ${ }^{104}$ We must ask, for

\footnotetext{
${ }^{98}$ Cohen 1978, 77-8.

${ }^{99}$ Cohen 1978, 77-8.

100 Sayer 1995, 182.

101 Jessop 2003, 9.

102 Jessop 2001, 101.

${ }^{103}$ Cohen 1978, 79.

${ }^{104}$ Cohen 1978, 79.
} 
example, what aspect of producing differentiates economic forms ${ }^{105}$, but we must also ask what the units are that we are seeking to characterise when we identify these different ways of producing.

Let me begin with the units. The traditional identification of modes of production with historical epochs implies that a mode of production is a feature of a whole social formation, that is a whole society. Both terms are problematic in the sense that they tend to assume what Daniel Chernilo calls methodological nationalism, that is, that societies are bounded by state borders. ${ }^{106}$ But whether the term is used in that sense, or to refer to a more global concept of society (and Marxists overwhelmingly do recognise that national formations are deeply embedded in a more global network of relations), it is clear from the arguments made earlier in this paper that in both cases economic processes are far too diverse for the social formation to be a viable unit to which to apply the concept. If it can be stripped of its methodologically nationalist connotations, the concept of a social formation is a useful one: it highlights the existence of a broader set of social relations within which capitalism, for example, may coexist with other economic forms. But because there may be multiple modes of production or economic forms within a social formation, the unit that can be identified unambiguously with a given economic form must be a smaller unit than the whole social formation.

Those thinkers who have sought to develop the argument that there might be multiple modes of production within a given social formation have tended to think of the unit of economic form as what we may call a site, or perhaps more accurately, a social entity. Thus, for example, the domestic labour debate often seems to have been conducted on the assumption that capitalism operated within commercial businesses, whereas some other economic form, if there was one, operated within the household. Although the concept of the household is typically identified with the space of the home, and that of the commercial business may be identified with the space of the factory, shop, or office, these identifications with geographical sites are somewhat crude. Thus, for example, when an office worker works from home she is engaged in activity on behalf of the business that employs her rather than household activity, and when a housewife shops in a supermarket she is engaged in activity on behalf of the household rather than work for the business that operates the shop. A more plausible version of the argument, therefore, identifies the social entity as the unit: in these cases the geographically spread business or household. Gibson-Graham, for example, generally argue in this way: they identify privately owned firms as capitalist, and a whole range of other social entities such as family businesses, households, and co-operatives as noncapitalist. ${ }^{107}$

Yet even this is unsatisfactory. Not all activities within the household can plausibly be seen as cases of the same economic form, and not all activities within commercial businesses can be seen as capitalistic. One way of making this argument would be to suggest that different economic forms operate in different households, as is implicit in Fraad, Resnick and Wolff, (note that they avoid the term mode of production). ${ }^{108}$ There is some value in this argument, but I suggest that it still misidentifies the unit of analysis. Even within one and the same household multiple economic forms

\footnotetext{
${ }^{105}$ I use the term economic form abstractly to refer to some way of labelling different types of economic organisation. Mode of production would be one possible concretisation of economic form, and this paper develops an alternative concretisation.

${ }^{106}$ Chernilo 2007, chapter 1.

${ }^{107}$ For example, Gibson-Graham 2006b, 65-6.

${ }^{108}$ Fraad, et al. 1994.
} 
may be at work. Thus, for example, some households mix work done without direct renumeration by family members with work done as wage labour by outsiders working, for example, as nannies, housekeepers, cleaners or gardeners. Miriam Glucksmann, for example, documents some fascinating mixes of paid and unpaid domestic labour in her study of women workers in 1930s Lancashire. ${ }^{109}$ There is considerable scope for debate about what mode of production or economic form each of these forms of labour represents, but it seems clear that they are two different modes with different sets of social relations of production. Similarly, within commercial businesses wage labour is accompanied by activities that can more plausibly be regarded as parts of a gift economy: most notably the work that workers do to assist each other. ${ }^{110}$ Some of the cases of entanglement of the commodity and gift economies in the digital environment discussed above also illustrate the point: when a salaried programmer in a profit-oriented commercial software company spends time writing open source code that is freely given to users of the software concerned it is not clear that this can be neatly filed under "capitalist mode of production".

I propose, therefore, that the unit that we can characterise as belonging clearly to a specific economic form is neither the social formation nor the social entity, but rather specific acts or practices, where a practice is a tendency to act in a certain way. Thus, for example, in the case of workers helping each other out while they work as wage labourers for a commercial business, the practice of wage labour and the practice of appropriating surplus as profit are surely capitalist practices, while the practice of assisting one's fellow workers is not. Similarly, in the case of salaried programmers writing open source code, the practice of wage labour may be capitalist, as is the practice of selling support services at a profit, but the practice of writing open source code is a gift economy practice.

If we may take practices as the unit of economic form, we can move on to consider what aspect of producing is at issue when we seek to differentiate economic forms, and even whether it is really producing at all that is the focus of the concept. For Marx the definitional difference between different modes of production is the difference in the set of social relations in which production is embedded. ${ }^{111}$ Thus, under capitalism the decisive relation is that between wage labourers and the capitalists who employ them and sell their product, whereas under feudalism the decisive relation is between serfs and the landlords who have the right to a share of their produce or of their labour power. What differs between these is the social basis upon which the occupants of different class positions are able to claim a portion of the product of labour. While there may also be differing allocations of control over the labour process, these do not seem to be definitional of either the class roles or the mode of production. Thus, despite the apparent focus of the term on production, it is the acts of appropriation of the product that are definitional of the different modes of production. A mode of production, we may say, is defined by the social relations that determine the appropriation of its products.

This appropriation, under capitalism, is the product of a series of different processes, spread over time. The practice of wage labour involves at least three logical stages: the contract, the labour, and

\footnotetext{
${ }^{109}$ Glucksmann 2012 [2000], chapter 3.

${ }^{110}$ Sayer 2004, 10.

111 "In the social production of their life, men enter into definite relations that are indispensable and independent of their will... The sum total of these relations of production constitutes the economic structure of society" Marx 1978 [1859], 4.
} 
the payment of the wage. As a result of undergoing the first two processes, the worker is entitled to receive, and generally does receive, the wage, and in this form appropriates her share of the product. Similarly, for the capitalist, appropriation depends on a practice with multiple stages: a contract that grants them ownership of the product of labour, the production process itself, and selling the product for more than its cost of production. The capitalist mode thus depends, not on one single practice, but on a combination of at least two practices: the practice of wage labour, and the practice of capitalists taking possession of the product and selling it as a commodity.

At least two consequences follow. First, appropriation and thus the character of the economic form (and even the character of Marx's modes of production) depends not only on acts of production but also on acts of transfer: transfers of products and sometimes of money. ${ }^{112}$ In the capitalist case these transfers take the form of exchange but there is no necessity for this to be the case. The serf's transfer of a share of their product to the landlord, for example, is not an exchange; nor is the transfer of a parent's caring services to their child. Second, modes of production depend on complexes of multiple practices, and it is only when the full complex is present that forms like capitalism may be said to exist. Wage labour alone, for example, is not enough to give us capitalism, since people may work for wages in a variety of non-capitalist enterprises. ${ }^{113}$ Nor is commodity production enough to give us capitalism, since individuals working alone, or family businesses that do not pay wages may produce and sell commodities. ${ }^{114}$

\section{Complexes of appropriative practices}

There is more to be said about these complexes, but we have reached a point where we can reflect again on terminology. If the term mode of production is indeed too wedded to the monolithic conception of a form that dominates particular epochs to be repositioned without dispute and confusion, how can we improve on it? Given that the distinction between practices discussed above depends on their different implications for the appropriation of products of labour, and given that Marx's different modes depend not just on single practices but on complexes of separable practices, I propose to use the term complex of appropriative practices or CAP for short.

Appropriative is perhaps not an ideal term, as it sometimes has the connotation that the person who receives the benefit actively takes it, and it is not my intention to suggest this. Unfortunately alternative terms tend to have directly opposite and equally unsatisfactory connotations - allocative and distributive can both seem to imply that the person who provides the benefit actively determines who receives it. Transfer is perhaps more suitable in this respect, as it is more neutral about who is in control of the process, but there isn't a cognate adjective. The best I can do here is point out that my use of the term appropriative carries no implication as to who is in charge of the process of transfer. Similarly, I should make clear that my use of the term does not imply any ethical judgement about the practices concerned, unlike the occasional use of the term appropriative practices in cultural and religious studies, where it generally seems to indicate disapproval of the practice concerned. ${ }^{115}$ Indeed, one virtue of the term is that in using it I seek to distance myself from

\footnotetext{
${ }^{112}$ This approach thus resonates with Fraad, Resnick and Wolff's characterisation of class processes as relating to "production, appropriation and distribution", although they remain tied to the labour theory of value Fraad, et al. 1994, 2.

${ }^{113}$ For a contrary Marxist argument, see Cohen 1978, 181-3.

114 Gibson-Graham 2006a, 263; Sayer 1995, 181.

115 For example, Welch 2007.
} 
the connotation that appropriations by anyone other than the producer of the product concerned are necessarily exploitative. ${ }^{116}$ I also depart from Marx in that, according to Balibar, he uses the term appropriation to include the process of production itself, which he regards as an appropriation of nature by the producer, ${ }^{117}$ whereas my usage is confined to the division of the spoils of the act of production.

This concept of a complex of appropriative practices, I argue, has several advantages over the monolithic conception of a mode of production (though I leave open the possibility that the two concepts may complement each other in some way, rather than being entirely mutually exclusive). Generalising, we may say with Hindess and Hirst that the monolithic conception of a mode of production leads to "the restriction of analysis to an extremely limited range of economic class relations and the consequent neglect of the problems of conceptualising more complex forms of class relations" ${ }^{118}$ Hindess and Hirst take the argument in other directions, but here I want to examine some of the ways in which CAPs allow us to theorise social relations more flexibly.

The first and most obvious of these, which follows from the argument of the earlier parts of this paper, is that there is no difficulty in theorising the coexistence of multiple CAPs. There is no longer a conflict, for example, between the belief that capitalism is an important element of the contemporary economy and the recognition that it governs only a minority of productive processes, and thus there is no longer a need to obscure the significance of the gift economy or indeed of other noncapitalist CAPs that coexist relatively stably alongside capitalism. Given this, we can abandon the attempt to reduce all contemporary class relations to capitalist appropriation of the product of wage labour that is characteristic of the most vulgar Marxism, and start to theorise the social relations and practices of appropriation that characterise these other CAPs. We need no longer, for example, ignore the appropriation of caring services by children in households because Marxism implies that this would make children exploiters of their parents, but rather examine the complex of processes in which this occurs as a CAP in its own right. We can escape from the hidebound pigeonholing of all social relations into what Folbre and Hartmann have called "a formulaic set of class processes", ${ }^{119}$ no longer constrained by the requirement that only processes that dominate an epoch can count as class processes.

As well as examining the coexistence of multiple complexes of appropriative practices within the economy, however, we now have the tools to examine such coexistence within specific sites or social entities. The fact that commercial firms are the site of capitalist CAPs is no longer a theoretical obstacle to the recognition that they may also be the site of other forms of appropriative practice. Nor is the argument that households are the site of gift-forms of appropriative practice compromised by recognising that they may also be the site of wage labour, whether it is capitalist (e.g. when an agency supplies cleaning staff) or not (e.g. when a self-employed cleaner contracts to provide a service). The household, in this perspective, becomes the site of moments of appropriation that operate within the frames of a variety of different complexes of appropriative practices. It is, we may say, a mixed economy of practices in its own right. Struggles within the household over the

\footnotetext{
${ }^{116}$ Cf Cohen 1978, 332.

${ }^{117}$ Althusser and Balibar 2009 [1968], 238.

118 Hindess and Hirst 1972, 2.

${ }^{119}$ Folbre and Hartmann 1994, 59.
} 
division and control of domestic labour may then also be theorised as struggles over the mix, struggles over which complex of appropriative practices is to prevail in which circumstances.

Relaxing the requirement that an economic form must correspond to the dominant form of an epoch also makes it easier to theorise varieties of a form. If, for example, the general form of the capitalist CAP can be characterised as suggested above by the combination of wage labour and commodity production, we can postulate varieties of capitalism in which this general form is combined in a larger complex with further appropriative practices. Thus, for example, we might distinguish between private capitalism in which the capitalist is an individual, and joint-stock capitalism in which ultimate rights to control capital and share in its appropriation of profit are distributed across a larger group through the practices of shareholder voting in general meetings and dividend distribution. Marxist thinkers have certainly made such distinctions already; as Jessop argues, for example, "there is no logic of capital but a series of logics with a family resemblance, corresponding to different modes of regulation and accumulation strategies". ${ }^{120}$ The concept of appropriative practices may be compatible with readings of the concept of mode of production that allow such diversity, if they can also be reinterpreted to address the other concerns raised here.

One of the most valuable features of Marx's work on modes of production is his examination of the mechanisms through which capitalism produces systemic effects such as the drive to growth, a tendency to cycles of boom and slump, and a tendency to extend capitalist commodity production progressively into wider territories and more products. To put the argument in terms borrowed from contemporary realist theory, these are emergent effects that result from those interactions of individuals and firms that are produced by the appropriative practices that are characteristic of capitalism. I would argue that when individuals and agents interact in these ways they form larger collectives - though not necessarily collectives that we should identify with the concepts of society or social formation - with the causal power to produce these tendencies.

If this is the case, then we must ask what the mechanisms are that generate these causal powers and tendencies, and precisely what relations do they depend upon? It is not at all clear, for example, that the combination of wage labour and commodity production, even when aggregated up to a macro scale, is enough to produce all of these tendencies. Do we need to identify further practices that interact with these to offer a full account of these systemic tendencies of capitalism? Might it be, for example, that we need to add certain capital market practices to the postulated complex before we can explain the orientation of capitalists to the accumulation of capital that generates the tendency to progressively extend commodity production? Different varieties of capitalism, characterised by the addition of further practices to the basic set that defines capitalism in general, may have different systemic consequences, and tracing the development of those practices may allow us to explain developments in the systemic effects of capitalism.

The CAP approach, however, also enables us to go further than this. Now that we have recognised the coexistence of multiple CAPs, we can consider what systemic effects might arise from the interaction of different CAPS. In practice, radical thinkers have been doing this for a long time, but they have always faced objections to any treatment that gives equal status to CAPs other than the mode of production considered dominant in the epoch concerned. Marx himself theorised the reproduction of labour power in the household, but only as a kind of auxiliary function of capitalist

120 Jessop 2001, 105. 
exploitation, yet the thrust of his argument is that the capitalist form is utterly dependent upon these other forms of production and appropriation. ${ }^{121}$

More recently than Marx, the French Regulation School theorists have argued that the capitalist economy has gone through a series of regimes of accumulation marked, among other things, by changing relations "between capitalism and non-capitalist modes of production". ${ }^{122}$ Thus, for example, Aglietta argues that in the United States in the nineteenth century capitalism benefitted from an environment in which its workers depended on non-commodity relations in the realm of domestic production to supply much of their consumption needs, as a result of remaining embedded in "the extended family and neighbourhood community". ${ }^{123}$ This allowed wages to be low; but later the development of heavy industry "enforces the total uprooting that is characteristic of the wage relation: the separation of labour power from all its conditions of existence" with the result that wages had to rise to cover the cost of reproducing labour power once this could no longer be subsidised by non-commodity relations of production. ${ }^{124}$ In the terms I have developed here, this is a different conjunction of complexes of appropriative practices that produces quite different systemic effects. ${ }^{125}$

\section{Where do we go from here?}

This paper has traced a thought process that is still in motion - beginning from the unrecognised importance of the contemporary gift economy and progressing to a re-evaluation of one of the central terms in the social ontology of political economy. It remains unclear how closely this tangent might approach to the centre of the problem of alternative futures; this will clearly depend on further development of the argument. Let me close this paper by suggesting three sets of issues that arise from the argument so far.

First, there are certain tasks that would seem to be required to develop the argument. If, in particular, the connection to the gift economy is to be completed, then we will need to identify the various complexes of appropriative practices at work in the gift economy. We should also consider what systemic effects these practices have already, and might have in the future, and how they interact with capitalist CAPs to produce hybrid emergent properties. What are the consequences of the gift economy, for example, for the mechanisms of capitalism postulated by Marx, and indeed Keynesian and neoclassical economists? And how are the emergent properties of gift economies impacted by various forms of entanglement with capitalist production? These are largely new tasks for political economy since both the neoclassical and Marxist approaches simplify the scientific task by ignoring the non-commodity economy. And yet they are tasks that could make important contributions to discussions on the viability and achievability of real utopias based on these practices.

\footnotetext{
${ }^{121}$ Marx 1954 [1867], chapter 6.

122 Brenner and Glick 1991, 47.

${ }^{123}$ Aglietta 2000 [1976], 80.

${ }^{124}$ Aglietta 2000 [1976], 81.

${ }^{125}$ This is not to say that the Regulation School would accept other parts of my argument here. Only a few lines later, for example, Aglietta argues that "there certainly is a universal extension of the capitalist mode of production in the social formations in which it is implanted" Aglietta 2000 [1976], 81. For him, it seems, dependence on other modes of production is no more than a transitional phenomenon.
} 
Secondly, I have said very little about the relation of this argument to critical realism, though I hope it is clear that it is built on realist foundations. Although I have not mentioned them, this approach to practices rests firmly on realist concepts such as the TMSA, morphogenetic cycles, and norm circles. ${ }^{126}$ Perhaps the most striking implication is that this is the beginnings of an argument in the field of critical realist political economy. Relatively little substantive critical realist work has been done in political economy, but a number of scholars have discussed the relation between critical realism and Marxism and further work on this tangent should engage with their contributions. ${ }^{127}$

Finally, what is the political significance of the argument, and in particular its significance for organising alternative futures? On the one hand, it provides grounds for some limited optimism: the domination of our economies by capitalism is less than it might seem in the light of the prevailing discourses of the economy, and it must be possible to build alternatives alongside capitalist economic practices since this is already occurring. Indeed, it is only if we do build alternatives alongside capitalism that viable alternative economic futures can be developed, and we should welcome the work of thinkers like Wright and Benkler who are examining some of the ways in which this could occur. On the other hand, however, this optimism must be qualified. Alternative appropriative practices can themselves be entangled in capitalist forms, and ultimately the viability of alternative futures will depend not only on growing them within our existing economy but also on finding ways to criticise and curtail the role of capitalist appropriative practices. Capitalism, despite being only part of our contemporary economy, is still capable of generating massive harms - notably extreme exploitation, alienation, inequality, massive distortions in the use of resources, environmental damage, and support for oppressive political regimes. It is still backed by enormous political and discursive power, and it constantly tends to subvert alternatives to its thirst for profit. Political work to overcome these harms and counter this power will never become redundant; but we will never be able to overcome them without viable economic alternatives to put in the place of capitalist appropriative practices. Attending to the place of giving in our existing economies helps to open our eyes to the opportunities for such alternatives.

\section{Bibliography}

Ackerman, B., A. Alstott, and P. Van Parijs 2006. Redesigning Distribution. London: Verso.

Aglietta, M. 2000 [1976]. A Theory of Capitalist Regulation. London: Verso.

Albert, M. 2003. Parecon: Life After Capitalism. London: Verso.

Alexa.com 2013. Top 500 Global Sites. http://www.alexa.com/topsites.

Althusser, L., and É. Balibar 2009 [1968]. Reading Capital. London: Verso.

Anderson, C. 2009. Free: The future of a radical price. New York: Random House.

Anderson-Gott, M., G. Ghinea, and B. Bygstad 2011. 'Why do commercial companies contribute to open source software?' International journal of information management 32(2): 106-17.

Archer, M. S. 1995. Realist Social Theory: The Morphogenetic Approach. Cambridge: Cambridge UP.

Benkler, Y. 2002. 'Coase's Penguin, or, Linux and The Nature of the Firm.' Yale Law Journal 112(3): 369-446.

Benkler, Y. 2004. 'Sharing Nicely.' Yale Law Journal 114(2): 273-358.

\footnotetext{
${ }^{126}$ Archer 1995; Bhaskar 1998 [1979]; Elder-Vass 2010.

${ }^{127}$ For example, Brown, et al. 2001; Creaven 2007; Fleetwood 2011; Jessop 2003; Sayer 1995.
} 
Benkler, Y. 2013. 'Practical Anarchism.' Politics and Society 41(2): 213-51.

Berking, H. 1999. Sociology of giving. London: Sage.

Bhaskar, R. 1993. Dialectic: the pulse of freedom. London: Verso.

Bhaskar, R. 1994. Plato etc. London: Verso.

Bhaskar, R. 1998 [1979]. The possibility of naturalism. 3rd edn. London: Routledge.

Brenner, R., and M. Glick 1991. 'The Regulation Approach.' New Left Review I(188): 45-119.

Brown, A., S. Fleetwood, and J. Roberts, eds 2001. Critical Realism and Marxism. London: Routledge.

Cammaerts, B. 2011. 'Disruptive sharing in a digital age: Rejecting neoliberalism.' Continuum: Journal of Media and Cultural Studies 25(1): 47-62.

Charities Aid Foundation 2012. World giving index. https://www.cafonline.org/PDF/WorldGivingIndex2012WEB.pdf.

Cheal, D. J. 1988. The gift economy. London: Routledge.

Chernilo, D. 2007. A social theory of the nation-state. Abingdon: Routledge.

Cohen, G. A. 1978. Karl Marx's Theory of History: A Defence. Oxford: Clarendon Press.

Corbet, J., G. Kroah-Hartman, and A. McPherson 2012. Linux Kernel Development: The Linux Foundation.

Creaven, S. 2007. Emergentist Marxism. Abingdon: Routledge.

Donati, P. 2003. 'Giving and Social Relations.' International Review of Sociology 13(2): 243-72.

Elder-Vass, D. 2010. The Causal Power of Social Structures. Cambridge: Cambridge UP.

Elder-Vass, D. 2014. 'Commerce, community and digital gifts.' In Commerce and Community, eds R. F. Garnett, P. Lewis and L. Ealy. Abingdon: Routledge.

Fleetwood, S. 2011. 'Laws and tendencies in Marxist political economy.' Capital and class 36(2): 23562.

Folbre, N., and H. Hartmann 1994. 'The persistence of patriarchal capitalism.' In Bringing it all back home, eds H. Fraad, S. Resnick and R. Wolff, 57-62. London: Pluto.

Forte, A., V. Larco, and A. Bruckman 2009. 'Decentralization in Wikipedia governance.' Journal of Management Information Systems 26(1): 49-72.

Fraad, H., S. Resnick, and R. Wolff 1994. Bringing it all back home. London: Pluto.

Fuchs, C. 2008. Internet and Society. New York: Routledge.

Gibson-Graham, J. K. 2006a. The End of Capitalism (As we knew it). Minneapolis: University of Minnesota Press.

Gibson-Graham, J. K. 2006b. A Postcapitalist Politics. Minneapolis: University of Minnesota Press.

Gimenez, M. E. 1997. 'Review of Bringing it all back home by Fraad, Resnick \& Wolff.' Cultural Logic 1(1)

Glucksmann, M. 2012 [2000]. Cottons and Casuals. Abingdon: Routledge.

Godbout, J., and A. Caillé 1998. The World of the Gift. Montreal: McGill-Queen's UP.

Graeber, D. 2011. Debt: the first 5,000 years. New York: Melville House.

Hartwig, M., ed. 2007. Dictionary of critical realism. Abingdon: Routledge.

Hindess, B., and P. Hirst 1972. Mode of Production and Social Formation. London: Macmillan.

Hodgson, G. M. 1999. Economics and Utopia. London: Routledge.

Ironmonger, D. 1996. 'Counting Outputs, Capital Inputs and Caring Labor: Estimating Gross Household Product.' Feminist Economics 2(3): 37-64.

Jessop, B. 2001. 'Capitalism, the Regulation Approach, and Critical Realism.' In Critical Realism and Marxism, eds A. Brown, S. Fleetwood and J. Roberts. London: Routledge.

Jessop, B. 2003. The crisis of the national spatio-temporal fix and the ecological dominance of globalizing capitalism Lancaster University Department of Sociology.

http://www.lancaster.ac.uk/sociology/research/publications/papers/iessop-crisis-of-thenational-spatio-temporal-fix.pdf.

Kinna, R. 2014. 'Practising (for) utopia.' TBA

Kropotkin, P. 2006 [1902]. Mutual Aid. Mineola, NY: Dover.

Levy, S. 2011. In the Plex. New York: Simon \& Schuster. 
Linux Foundation 2012. How Linux is built [Video]. https://www.youtube.com/watch?v=yVpbFMhOAwE, also available at http://www.linuxfoundation.org/.

Marx, K. 1954 [1867]. Capital, Volume 1. London: Lawrence \& Wishart.

Marx, K. 1978 [1844]. 'Economic and Philosophical Manuscripts of 1844.' In The Marx-Engels Reader, ed. R. C. Tucker, 66-125. New York: WW Norton.

Marx, K. 1978 [1859]. 'Preface to a Contribution to the Critique of Political Economy.' In The MarxEngels Reader, ed. R. C. Tucker, 3-6. New York: WW Norton.

Matthaei, J. 1994. 'Surplus labor, the household, and gender oppression.' In Bringing it all back home, eds H. Fraad, S. Resnick and R. Wolff, 42-49. London: Pluto.

Molyneux, M. 1979. 'Beyond the Domestic Labour Debate.' New Left Review I(116)

Negru, I. 2010. 'The plural economy of gifts and markets.' In Economic Pluralism, eds R. F. Garnett, E. K. Olsen and M. Starr, 194-204. Abingdon: Routledge.

Nelson, J. A. 1993. 'The study of choice or the study of provisioning? Gender and the definition of economics.' In Beyond Economic Man, eds M. A. Ferber and J. A. Nelson, 23-36. Chicago: University of Chicago Press.

O'Sullivan, D. 2009. Wikipedia: a new community of practice? Farnham: Ashgate.

Reagle, J. 2010. Good Faith Collaboration. Cambridge, MA: MIT Press.

Red Hat 2012. The world's leading provider of open source enterprise IT products and services

[Corporate brochure]. http://www.redhat.com/rhecm/rest-

rhecm/icr/repository/collaboration/icr:system/icr:versionStorage/fb405b2d0a0526023d2a9

fc5eedad019/2/jcr:frozenNode/rh:resourceFile.

Roemer, J. E. 1994. A Future for Socialism. London: Verso.

Sayer, A. 1995. Radical Political Economy.

Sayer, A. 1997. 'Critical Realism and the Limits to Critical Social Science.' Journal for the Theory of Social Behaviour 27(4): 473-88.

Sayer, A. 2004. Moral Economy Department of Sociology, Lancaster University. http://www.lancs.ac.uk/fass/sociology/papers/sayer-moral-economy.pdf.

Stallman, R. 2010. Free Software, Free Society. 2nd edn. Boston MA: GNU Press.

Weber, S. 2004. The success of open source. Cambridge MA: Harvard UP.

Welch, C. 2007. 'Complicating Spiritual Appropriation.' Journal of Alternative Spiritualitis and New Age Studies 3: 97-117.

Williams, C. C. 2003. 'Evaluating the penetration of the commodity economy.' Futures 35: 857-68.

Wright, E. O. 2010. Envisioning Real Utopias. London: Verso.

\section{Author bio}

Dave Elder-Vass is a Senior Lecturer in sociology at Loughborough University. His writing on social ontology and social theory includes two recent books: The Causal Power of Social Structures (2010) and The Reality of Social Construction (2012). Currently, he is working on issues in the social ontology of economic phenomena, on the nature of cultural communities, and on giving as an alternative to market exchange. 